\title{
STRATEGI PEMECAHAN MASALAH \\ DALAM MENYELESAIKAN SOAL CERITA PADA MATERI PERSAMAAN DAN \\ PERTIDAKSAMAAN LINEAR SATU VARIABEL \\ SISWA KELAS VII A SMP KRISTEN 02 SALATIGA
}

\author{
Mega Ristiana \\ Mega_ristiana@yahoo.com \\ Program Studi Pendidikan Matematika \\ FKIP - Universitas Kristen Satya Wacana \\ Novisita Ratu \\ novisita.ratu@staff.uksw.edu \\ Program Studi Pendidikan Matematika \\ FKIP - Universitas Kristen Satya Wacana \\ Tri Nova Hasti Yunianta \\ trinova.yunianta@staff.uksw.edu \\ Program Studi Pendidikan Matematika \\ FKIP - Universitas Kristen Satya Wacana
}

\begin{abstract}
ABSTRAK
Penelitian deskriptif kualitatif ini bertujuan untuk mengetahui strategi pemecahan masalah dalam menyelesaikan soal cerita pada materi persamaan dan pertidaksamaan linier satu variabel oleh siswa kelas VII A SMP Kristen 02 Salatiga berdasarkan 11 strategi pemecahan masalah yang dikemukakan oleh Reys. Metode penelitian yang digunakan adalah metode penelitian deskriptif kualitatif. Responden dalam penelitian ini yaitu siswa kelas VII A yang berjumlah 20 siswa, yang selanjutnya dengan teknik purpose sampling terpilih 2 siswa sebagai subyek penelitian. Hasil analisis data menunjukkan bahwa, untuk pekerjaan siswa yang jawabannya benar dari soal nomor satu hingga nomor lima kebanyakan siswa menggunakan strategi mengidentifikasi informasi yang diinginkan, diberikan dan diperlukan, dan strategi menggunakan kalimat terbuka. Ada yang berbeda untuk soal nomor dua beberapa siswa ditambahkan dengan strategi membuat gambar.Hasil pekerjaan siswa yang salah kebanyakan hanya menggunakanstrategi mengidentifikasi informasi yang diinginkan, diberikan dan diperlukan, tetapi siswa hanya mampu memilah informasi dengan menuliskan apa saja yang diketahui di dalam soal dan belum sampai pada memilih langkah-langkah penyelesaian yang sesuai dengan soal. Beberapa siswa ditambahkan strategi menggunakan kalimat terbuka atau menggunakan variabel-variabel sebagai pengganti kalimat dalam soal. Siswa sudah mampu menuliskan apa saja yang diketahui di dalam soal dan sudah mampu mengubah variabelnya namun siswa belum mampu menyelesaikan soal dengan baik.
\end{abstract}

Kata Kunci: strategi pemecahan masalah, reys, persamaan dan pertidaksamaan linier satu variabel 


\section{PENDAHULUAN}

Pelajaran matematika di sekolah sangatlah penting bagi siswa, dengan mempelajari matematika diharapkan siswa dapat menguasai seperangkat kompetensi yang telah ditetapkan. Oleh karena itu, penguasaan materi matematika bukanlah tujuan akhir dari pembelajaran matematika, akan tetapi penguasaan materi matematika hanyalah jalan mencapai penguasaan kompetensi. Haji (1994), mengemukakan bahwa soal yang dapat digunakan untuk mengetahui kemampuan siswa dalam bidang studi matematika dapat berbentuk soal cerita dan bukan soal cerita. Soal cerita penting untuk diberikan kepada siswa guna melatih siswa dalam menyelesaikan masalah.

Menurut Hudojo dalam Indrajaya (2012), di dalam matematika, suatu pertanyaan atau soa merupakan suatu masalah apabila tidak terdapat aturan/hukum tertentu yang segera dapat digunakan untuk menjawab atau menyelesaikannya. Hal ini berarti bahwa suatu soal matematika akan menjadi masalah apabila tidak segera ditemukan petunjuk pemecahan masalah berdasarkan data yang terdapat dalam soal. Menurut Sutriyono dalam Hardini (2012), masalah yang baik harus memenuhi tiga kasus yaitu: a) penerimaan di mana individu menerima masalah; b) hambatan yaitu kebiasaan dalam memberikan tanggapan dan pola pengerjaan; dan c) eksplorasi yaitu memaksa individu untuk mengeksplorasi metode baru dalam pengerjaan. Usman (2007)menyatakan bahwa masalah dalam matematika adalah segala sesuatu atau kondisi yang memerlukan suatu tindakan penyelesaian serta pada saat situasi tersebut muncul diperlukan suatu usaha untuk mendapatkan cara yang dapat digunakan untuk mengatasinya.

Fakta di lapangan menunjukkan bahwa pembelajaran matematika untuk materi persamaan dan pertidaksamaan linier satu variabel pada tingkat Sekolah Menengah Pertama (SMP) khususnya kelas VII masih banyak yang belum memahami, hal itu disampaikanoleh guru matematika SMP Kristen 2 Salatiga. Materi ini harus benarbenar dipahami dari segi konsep, prosedur serta keterampilan berhitung, karena untuk menghindari kesalahan-kesalahan yang dialami siswa dalam menyelesaikan soal. Siswa mempunyai berbagai macam strategi dalam menyelesaikan soal cerita matematika. Pentingnya siswa menggunakan strategi dalam menyelesaikan soal cerita dapat dilihat dari pengamatan di lapangan, sampai saat ini proses pembelajaran yang berpusat pada siswa masih mengalami banyak kendala, seperti rendahnya kemampuan siswa dalam menganalisis masalah, dalam merancang rencana penyelesaian masalah dan dalam melaksanakan perhitungan terutama yang berkaitan dengan materi persamaan dan pertidaksamaan linier satu variabel khususnya proses pemecahan masalah dalam soal cerita.

Menurut Hamzah dalam Indrajaya (2012), pemecahan masalah dapat berupa menciptakan ide baru, menemukan teknik atau produk baru. Pemecahan masalah mempunyai arti khusus di dalam pembelajaran matematika, istilah tersebut mempunyai interpretasi yang berbeda, misalnya menyelesaikan soal cerita yang tidak rutin dan mengaplikasikan matematika dalam kehidupan sehari-hari. Menurut Polya dalam Nuralam (2009), pemecahan masalah adalah suatu usaha untuk mencari jalan keluar dari suatu kesulitan guna mencapai suatu tujuan yang tidak begitu mudah dapat dicapai. Penyelesaian masalah dalam soal cerita diperlukan langkah-langkah dalam pengerjaannya. Terdapat beberapa langkah pemecahan masalah dalam matematika menurut Polya, 
dalam pemecahan masalah terdapat empat langkah yang harus dilakukan yaitu: a) memahami masalah; b) merencanakan pemecahannya; c) menyelesaikan masalah sesuai rencana langkah kedua; dan d) memeriksa kembali hasil yang diperoleh.Langkah merencanakan pemecahan masalah terdapat strategi yang digunakan. Menurut Reys (1998) disebutkan beberapa macam strategi pemecahan masalah yaitu: a) Act It Out (beraksi); b) membuat gambar atau diagram; c) mencari pola; d) membuat tabel; e) menghitung semua kemungkinan secara sistematis; f) menebak dan menguji; g) bekerja mundur; h) mengidentifikasi informasi yang diinginkan, diberikan, dan diperlukan; i) menggunakan kalimat terbuka; j) menyelesaikan masalah yang lebih sederhana atau serupa; k) mengubah pandangan.

Beberapa penelitian yang telah dilakukan terkait pemecahan masalah Polya dan strategi pemecahan masalah Reys misalnya, Imroatun (2014) dengan judul Strategi Pemecahan Masalah Matematika Siswa Kelas VII SMP Kristen 02 Salatiga Ditinjau dari Langkah Polya. Penelitian deskriptif kualitatif ini hasil temuannya adalah subyek penelitian dengan hasil belajar tinggi melaksanakan tiga langkah pemecahan dalam menyelesaikan soal yang diberikan. Ketiga langkah yang dilakukan adalah memahami masalah, membuat rencana pemecahan masalah, dan melaksanakan rencana pemecahan masalah. Strategi yang digunakan untuk membantu memecahkan masalah adalah memahami masalah, membuat rencana pemecahan masalah dan melaksanakan rencana pemecahan masalah, sedangkan strategi yang digunakan adalah strategi menuliskan kalimat terbuka. Baik subyek dengan hasil belajar tinggi maupun rendah tidak melaksanakan langkah memeriksa kembali atas hasil yang telah diperoleh. Penelitian berikutnya adalah penelitian yang dilakukan oleh Mustika (2013) dengan judul Strategi Pemecahan Masalah Himpunan pada Siswa Kelas VII SMP Pangudi Luhur Tuntang. Hasil penelitiannya yaitu dari sebelas strategi pemecahan masalah menurut Reys yang dijadikan kajian teori, terdapat empat strategi yang digunakan siswa. Keempat strategi tersebut adalah strategi membuat tabel, strategi menghitung semua kemungkinan secara sistematis, strategi menebak dan menguji, dan yang terakhir strategi mengidentifikasi informasi yang diinginkan, diberikan dan diperlukan. Strategi yang paling banyak digunakan adalah strategi menebak dan menguji.

Berdasarkan pengamatan di lapangan, siswa menggunakan beberapa strategi dalam menyelesaikan soal cerita, tidak hanya menggunakan satu strategi, namun cara siswa dalam menyelesaikan soal cerita tersebut bervariasi. Hal itu di lihat dari cara siswa yang mengikuti sesuai ajaran guru, ada juga yang mengikuti cara dari saat siswa les dan ada yang belajar dari teman. Penelitian ini nantinya bertujuan agar guru atau peneliti mengetahui macam-macam strategi yang dimiliki siswa dalam menyelesaikan soal cerita dan supaya guru atau peneliti juga dapat menyesuaikan strategi yang tepat untuk siswa. Melihat adanya permasalahan yang dihadapi siswa terkait pemecahan masalah, maka akan dilakukan suatu penelitian. Mengingat beberapa penelitian yang dilakukan sebelumnya maka penelitian ini juga akan dilakukan untuk mengetahui strategi pemecahan masalah yang digunakan siswa dalam menyelesaikan soal cerita. Berdasarkan latar belakang di atas, maka akan dilakukan penelitian dengan judul "Strategi pemecahan masalah dalam menyelesaikan soal cerita pada materi persamaan dan 
pertidaksamaan linear satu variabel siswa kelas VII A SMP Kristen 02 Salatiga".

\section{METODE PENELITIAN}

Jenis penelitian ini adalah deskriptif kualitatif. Siswa yang terlibat dalam penelitian ini adalah siswa kelas VIIASMP Kristen 02 Salatiga dengan jumlah siswa yang mengikuti tes sebanyak 20 anak pada Semester 2 Tahun Ajaran 2014/2015. Pengambilan subyek oleh peneliti sebagai sampel sumber data, menggunakan teknik purposive sampling terpilih 2 siswa sebagai subyek penelitian. Hasil tes pemecahan masalah siswa dikelompokkan untuk setiap nomor dalam jawaban siswa yang benar dengan nilai tertinggi dan jawaban siswa yang salah dengan nilai terendah.

Teknik pengumpulan data untuk mendapatkan data yang relevan dalam penelitian ini menggunakan metode tes dan wawancara. Bentuk tes yang digunakan adalah tes uraian (tes essay). Wawancara dilakukan kepada guru dan siswa untuk mendapatkan informasi menyangkut masalah yang diajukan peneliti dan menggunakan percakapan verbal.

\section{HASIL PENELITIAN DAN PEMBAHASAN}

\section{Analisis Strategi Pemecahan Masalah}

Proses menganalisis data tidak hanya dilihat dari hasil akhir pekerjaan siswa tetapi dilihat juga proses pekerjaan siswa dalam menyelesaikan soal persamaan dan pertidaksamaan linier satu variabel, sehingga dapat dilihat strategi apa sajakah yang digunakan siswa dalam menyelesaikan soal. Terdapat 11 strategi pemecahan masalah menurut Reys (1998) yang digunakan peneliti untuk menganalisis hasil pekerjaan siswa. Strategi yang digunakan siswa dalam menyelesaikan soal persamaan dan pertidak-samaan linier satu variabel dibahas satu persatu tiap soal.
Pembahasan soal untuk nomor satu terdapat 20 siswa yang mengikuti tes dalam pemecahan masalah dengan materi persamaan dan pertidaksamaan linier satu variabel.Hampir semua siswa menjawab pertanyaan dengan benar dan hanya ada beberapa siswa yang menjawab salah. Banyak siswa yang menjawab benar adalah sebanyak 14 siswa dan yang menjawab salah sebanyak 6 siswa. Hasil jawaban siswa yang benar, menggunakan strategi yang sama dalam menyelesaikan soal, yaitu menggunakan strategimengidentifikasi informasi yang diinginkan, diberikan dan diperlukan, dan strategi menggunakan kalimat terbuka. Enam siswa yang menjawab salah, menggunakan strategi mengidentifikasi informasi yang diinginkan, diberikan dan diperlukan, namun indikator dalam memilih langkahlangkah penyelesain yang sesuai dengan soal belum tercapai.Hasil pekerjaan siswa dalam pemecahan masalah menurut Reys pada soal nomor satu dengan jawaban yang benar dapat dilihat pada Gambar 1.

Hasil pekerjaan yang dilakukan subyek menunjukkan bahwa siswa terlebih dahulu menuliskan apa yang diketahui di dalam soal, jadi siswa sudah mengerti apa saja yang diketahui di soal. Kemudian siswa menuliskan model matematikanya yang dimisalkan y adalah kenaikan posisi pesawat. Selanjutnya yang terakhir siswa menghitungnya dengan mengidentifikasi informasi yang sesuai dengan soal dan mengecek kembali hasil pekerjaannya. Jadi strategi yang digunakan untuk mengerjakan soal nomor satu sudah tepat dan sesuai.

Pembahasan untuk nomor dua banyak siswa yang menjawab benar adalah sebanyak 11 siswa dan yang menjawab salah sebanyak 9 siswa. Jawaban siswa dalam menyelesaikan soal yang hasilnya benar, hampir semua siswa meggunakan strategi yang sama, namun ada 


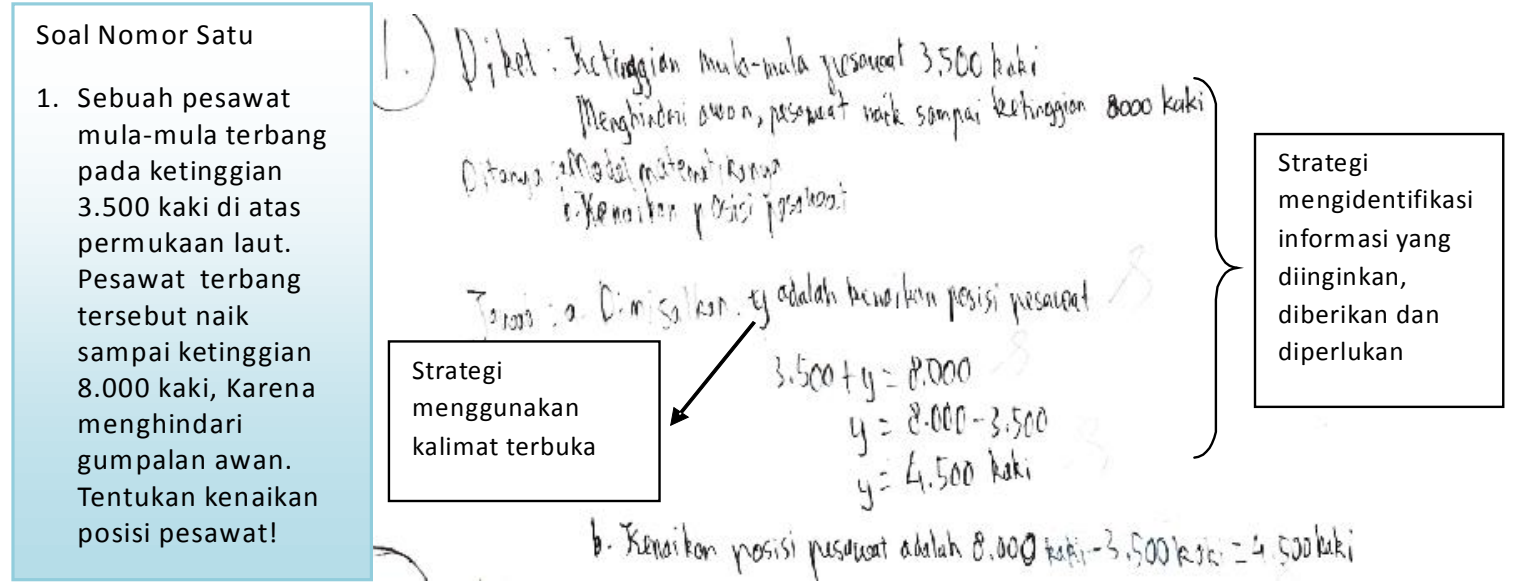

Gambar 1 Contoh Pekerjaan Siswa

juga yang menggunaan strategi berbeda namun jawabannya benar. Strategi yang digunakan siswa untuk jawaban yang benar dalam menyelesaikan soal beragam, yaitu empat siswa menggunakan strategi mengidentifikasi informasi yang diinginkan, diberikan dan diperlukan dan strategi menggunakan kalimat terbuka. Tujuh siswa menggunakan strategi seperti di atas, namun ditambahkan dengan strategi membuat gambar. Sembilan siswa yang menjawab salah, menggunakan strategi mengidentifikasi informasi yang diinginkan, diberikan dan diperlukan, namun indikator dalam memilih langkahlangkah penyelesaian yang sesuai dengan soal belum tercapai dan strategi menggunakan kalimat terbuka. Sebenarnya siswa sudah mampu menggunakan kalimat terbuka dalam soal, namun siswa yang kurang teliti maka jawaban atau dalam mengerjakan soal tidak tepat. Hasil pekerjaan siswa dalam pemecahan masalah menurut Reys pada soal nomor dua dengan jawaban yang benar dapat dilihat pada Gambar 2.

\section{Soal Nomor Dua}

2. Pak Robin memiliki kebun berbentuk persegi panjang. Panjang kebunnya dua kali lebarnya. Keliling kebun pak Robin adalah $48 \mathrm{~m}$.

a. Tentukan panjang dan lebar sesungguhnya!

b. Berapakah luas kebun tersebut?

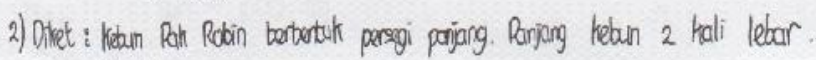
kell keain $=48 \mathrm{~m}$

Atanya: a. Tentuikon parjang dan lebar

b. Gerapa luas kelan??

Jaud : a) $48=(2 \times(2 l+l) \quad 424=3 l$
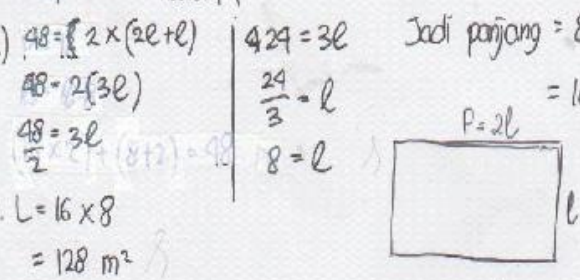

Strategi

mengidentifikasi

informasi yang

diinginkan, diberikan

dan diperlukan dan

Strategi menggunakan

kalimat terbuka

Gambar 2 Contoh Pekerjaan Siswa 
Hasil pekerjaan siswa dan hasil wawancara di atas menunjukkan bahwa siswa dapat menuliskan apa saja yang diketahui di dalam soal, sudah mampu menganalisis dan tahap-tahap mengerjakanpun sudah tepat dan ditambahkan menggambarkan agar mempermudah dalam mengerjakan. Siswa juga sudah mampu menggunakan kalimat terbuka yang dimisalkan $\mathrm{p}$ dan 1.

Pembahasan untuk soal nomor tiga menunjukkan bahwa dari 20 siswa yang mengerjakan soal, strategi atau cara yang di gunakan siswa dalam menyelesaikan soal hampir semuanya siswa sama. Strategi yang digunakan siswa dalam menyelesaikan soal yang jawabannya benar yaitu, 14 siswa menggunakan strategi mengidentifikasi informasi yang diinginkan, diberikan dan diperlukan, dan strategi menggunakan kalimat terbuka. Enam siswa yang menjawab salah, menggunakan strategi mengidentifikasi informasi yang diinginkan, diberikan dan diperlukan, namun indikator dalam memilih langkahlangkah penyelesain yang sesuai dengan soal belum tercapaidan strategi menggunakan kalimat terbuka.Hasil pekerjaan siswa dalam pemecahan masalah menurut Reys pada soal nomor tiga dengan jawaban yang benar dapat dilihat pada Gambar 3.
Hasil pekerjaan siswa dan wawancara di atas, menunjukkan bahwa siswa menggunakan strategi mengidentifikasi informasi yang diinginkan, diberikan dan diperlukannya itu menuliskan apa saja yang diketahui di dalam soal. Memisalkan x sebagai pengganti variabel hal tersebut termasuk di dalam strategi menggunakan kalimat terbuka. Mengerjakan dengan terstuktur dan cara yang tepat dengan strategi mengidentifikasi informasi yang diinginkan, diberikan dan diperlukan.

Pembahasan soal nomor empat menunjukkan bahwa banyak siswa yang menjawab benar hanya berjumlah 5 anak, dan kebanyakan siswa ternyata menjawab salah yaitu sebanyak 15 siswa. Strategi atau cara yang di gunakan siswa dalam menyelesaikan soal untuk jawaban benar sama semua. Mereka menggunakan strategi mengidentifikasi informasi yang diinginkan, diberikan dan strategi menggunakan kalimat terbuka atau pengganti variabel dalam soal. Limabelas siswa yang menjawab salah, menggunakan dua macam strategi berbeda dalam menyelesaikan soal. Sembilan siswa menggunakan strategi mengidentifikasi informasi yang diinginkan, diberikan dan diperlukan, namun indikator dalam memilih langkah-langkah

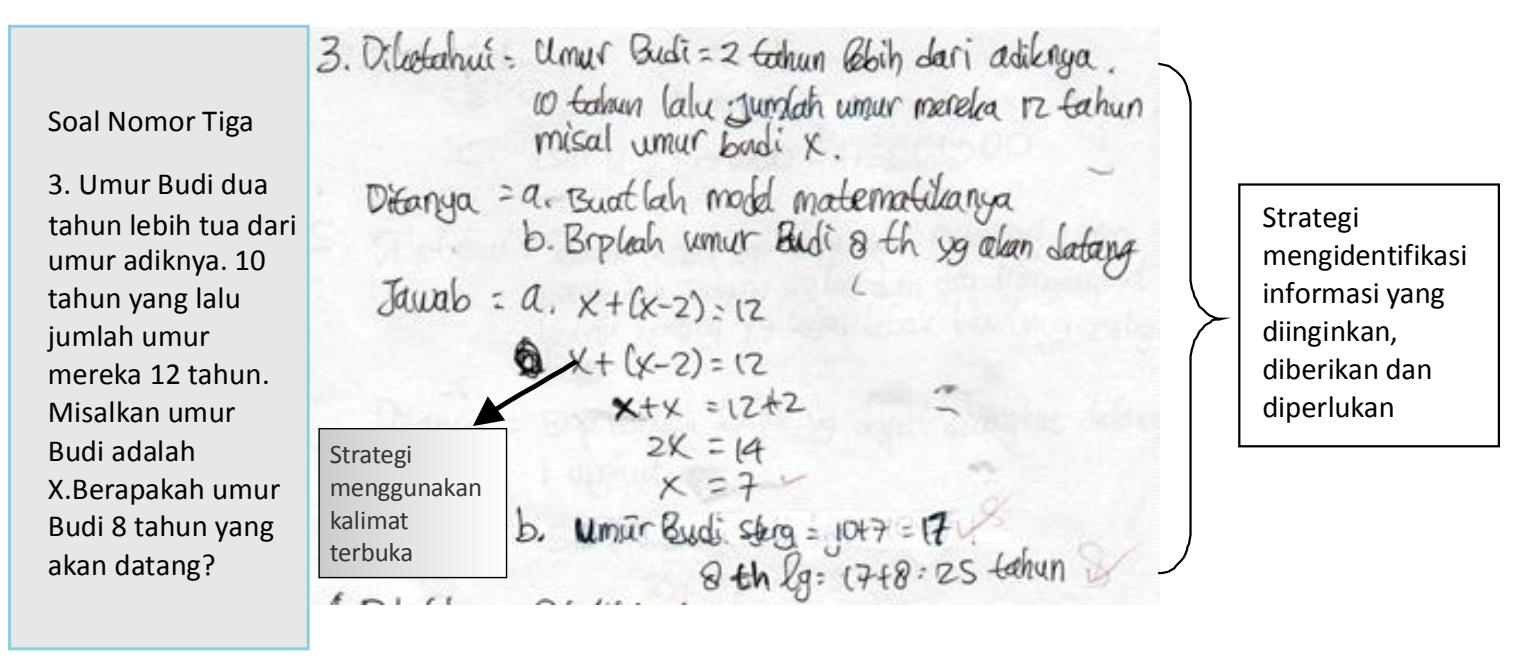

Gambar 3 Contoh Pekerjaan Siswa 
penyelesaian yang sesuai dengan soal belum tercapai dan strategi menggunakan kalimat terbuka. Enam siswa yang lain hanya menggunakan strategi mengidentifikasi informasi yang diinginkan, diberikan, namun indikator dalam memilih langkah-langkah penyelesaian yang sesuai dengan soal belum tercapai. Hasil pekerjaan siswa dalam pemecahan masalah menurut Reys pada soal nomor empat dengan jawaban yang benar dapat dilihat pada Gambar 4.
Pembahasan soal nomor lima menunjukkan bahwa 10 siswa menjawab benar dan 10 siswa menjawab salah. Strategi siswa yang digunakan untuk jawaban yang benar semuanya sama yaitu menggunakan strategi mengidentifikasi informasi yang diinginkan, diberikan dan diperlukan dan menggunakan kalimat terbuka. Sepuluh siswa yang menjawab salah, mereka hanya mampu menuliskan apa yang diketahui didalam soal. Hasil pekerjaan siswa dalam

Soal Nomor Empat

4. Pak Ketut akan membangun rumah di atas sebidang tanah berbentuk persegi panjang yang panjangnya $30 \mathrm{~m}$ dan lebarnya $(2 \mathrm{y}-1) \mathrm{m}$. Jika luas tanah pak Ketut kurang dari atau sama dengan $150 \mathrm{~m}^{2}$ :

a. berapakah lebar tanah pak Ketut yang paling besar?

b. biaya untuk membangun $1 \mathrm{~m}^{2}$ dibutuhkan $\mathrm{Rp} 2.500 .000,00$. berapakah biaya maksimal yang harus disediakan pak Ketut jika seluruh tanahnya dibangun?

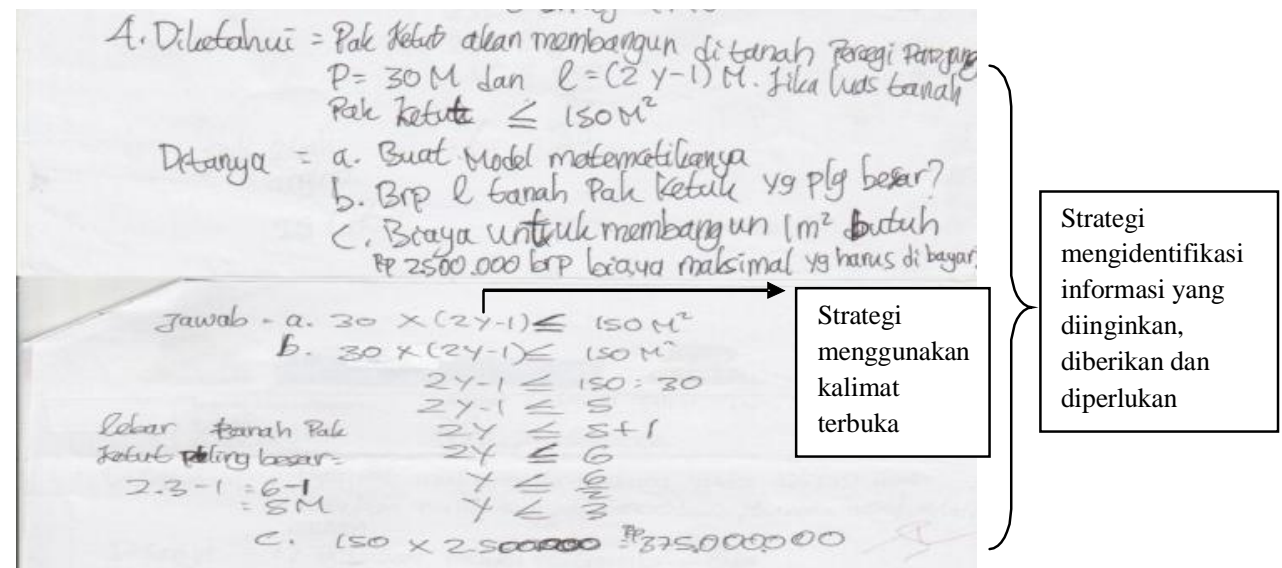

Gambar 4 ContohPekerjaan Siswa

Hasil pekerjaan siswa dan wawancara di atas, menunujukkan bahwa siswa tersebut telah menuliskan apa saja yang diketahui di dalam soal dengan menentukan permasalahan yang akan dijawab, memilah informasi penting untuk menjawabnya, dan memilih langkah-langkah penyelesaian yang sesuai dengan soal. Siswa juga telahmenggunakan variabel-variabel sebagai pengganti kalimat dalam soal dan menuliskan tanda pertidaksamaan yaitu tanda kurang dari atau sama dengan di dalam pekerjaan siswa. pemecahan masalah menurut Reys pada soal nomor lima dengan jawaban yang benar dapat dilihat pada Gambar 5. Jawaban yang salah dapat dilihat pada Gambar 6 .

Hasil pekerjaan siswa dan wawancara, menunujukkan bahwa siswa tersebut telah menggunakan strategi mengidentifikasi informasi yang diinginkan, diberikan dan diperlukan dan menggunakan kalimat terbuka. Siswa menuliskan apa saja yang diketahui di dalam soal dengan menentukan permasalahan yang akan dijawab, memilah 


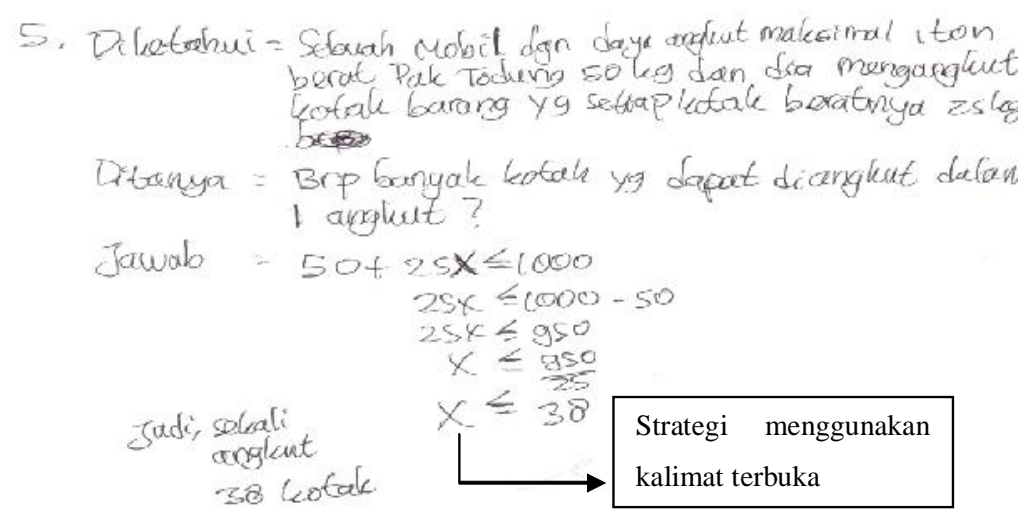

Strategi

mengidentifikasi

informasi yang

diinginkan,

diberikan dan

diperlukan

Gambar 5 ContohPekerjaan Siswa

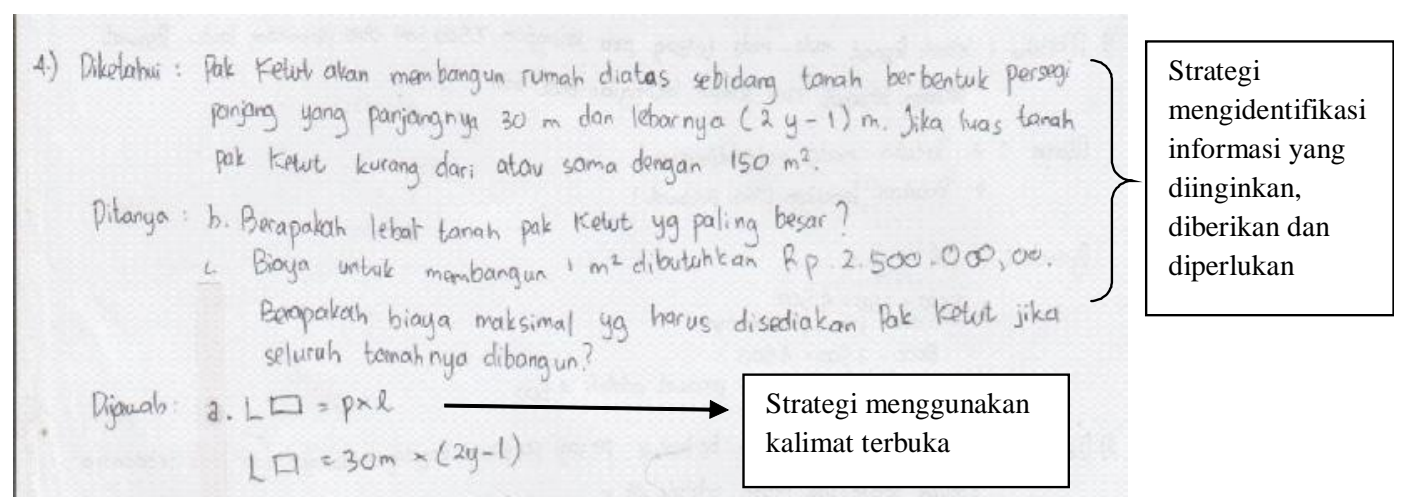

Gambar 6 Contoh Pekerjaan Siswa

informasi penting untuk menjawabnya, dan memilih langkah-langkah penyelesaian yang sesuai dengan soal. Siswa juga telah menggunakan variabel-variabel sebagai pengganti kalimat dalam soal.

Hasil pekerjaan siswa dan wawancara di atas, menunjukkan bahwa siswa tersebut sebenarnya telah menggunakan strategi mengidentifikasi informasi yang diinginkan, diberikan dan diperlukan, namun siswa hanya mampu memilah informasi dengan menuliskan apa saja yang diketahui di dalam soal dan menggunakan variabel sebagai pengganti kalimat dalam soal. Cara mengerjakannya belum bisa sampai menemukan jawaban yang benar.

\section{SIMPULAN}

Setelah melakukan penelitian dan menganalisis data yang terkait dengan strategi pemecahan masalah yang digunakan siswa SMP Kristen 2 Salatiga kelas VII A pada materi persamaan dan pertidaksamaan linier satu variabel. Terdapat 11 strategi pemecahan masalah menurut Reys yang digunakan peneliti untuk menganalisis. Hasil pekerjaan siswa dapat disimpulkan bahwa strategi yang digunakan siswa dalam mengerjakan soal untuk jawaban yang benar dari nomor satu sampai nomor lima kebanyakan siswa menggunakan strategi mengidentifikasi informasi yang diinginkan, diberikan dan diperlukan dan strategi menggunakan kalimat terbuka atau menggunakan variabelvariabel sebagai pengganti kalimat dalam soal. Ada yang berbeda untuk soal nomor dua beberapa siswa ditambahkan dengan strategi membuat gambar. Jawaban siswa yang salah untuk soal nomor satu hingga soal nomor lima siswa menggunakan strategimengidentifikasi informasi yang diinginkan, diberikan dan diperlukan, tetapi 
siswa hanya mampu memilah informasi dengan menuliskan apa saja yang diketahui di dalam soal dan belum sampai pada memilih langkah-langkah penyelesaian yang sesuai dengan soal. Beberapa siswa ditambahkan strategi menggunakan kalimat terbuka atau menggunakan variabel-variabel sebagai pengganti kalimat dalam soal. Siswa sudah mampu menuliskan apa saja yang diketahui di dalam soal dan sudah mampu merubah variabelnya namun siswa belum mampu menyelesaikan soal dengan baik.

Berdasarkan hasil penelitian, siswa sebaiknya mempelajari atau memahami strategi-strategi yang diajarkan guru agar saat mengerjakan soal siswa bisa, siswa sebaiknya belajar memahami soal cerita terlebih dahulu dan kemudian menggunakan strategi yang sesuai saat mengerjakan soal cerita, bagi guru matematika hendaknya mengenalkan atau mengajarkan berbagai macam strategi agar siswa tidak hanya menggunakan satu strategi, namun bisa menggunakan macam-macam strategi, guru matematika juga hendaknya menghargai strategi yang berbeda yang digunakan oleh siswa dalam menyelesaikan soal dengan benar.

\section{DAFTAR PUSTAKA}

Haji, Moch. 1994. Penanaman konsep soal cerita matematika. Yogyakarta: Imperium.

Hardani. 2012. Strategi Pemecahan Masalah Barisan dan Deret Siswa Kelas IX Sekolah Menengah Pertama Pangudi Luhur Tuntang. Skripsi. Universitas Kristen Satya Wacana.

Indrajaya. 2012. Strategi Pemecahan Masalah Dalam Menyelesaikan Soal Cerita Pada Materi SPLDV Siswa Kelas VIII Di SMP Kristen 2 Salatiga. Skripsi. Universitas Kristen Satya Wacana.

Nuralam. 2009. Pemecahan Masalah Sebagai Pendekatan dalam Belajar Matematika. Jurnal Edukasi, Vol. V, no. 1.

Reys, Robert E, dkk. 1998. Helping Children Learn Mathematics. USA: Avicom Company.

Sugiyono. 2010. Metode Penelitian Kuantitatif, Kualitatif dan R \& D. Bandung: Alfabeta.

Usman, Sudarmin. 2007. StrategiPemecahan Masalah Dalam Penyelesaian Soal Cerita di Sekolah Dasar. Jurnal Samudra ilmu: Vol 2. No 2. 